\title{
Pengaruh Pemberian Probiotik Berbeda dalam Sistem Akuaponik terhadap Laju Pertumbuhan dan Survival Rate Ikan Lele (Clarias sp.)
}

\section{Effect Addition of Different Probiotic in Aquaponic Systems Towards The Growth Rate and Survival Rate of Catfish (Clarias sp.)}

\author{
Ayu Herdianti Primashita ${ }^{1^{*}}$, Boedi Setya Rahardja ${ }^{2}$, dan Prayogo ${ }^{2}$ \\ ${ }^{1}$ Budidaya Perairan, Fakultas Perikanan dan Kelautan Universitas Airlangga, Surabaya 60115 \\ ${ }^{2}$ Departemen Manajemen Kesehatan Ikan dan Budidaya Perairan, Fakultas Perikanan dan Kelautan Universitas \\ Airlangga, Surabaya 60115 \\ *ayu.herdianti-12@fpk.unair.ac.id
}

\begin{abstract}
Abstrak
Ikan lele (Clarias sp.) merupakan merupakan ikan air tawar yang banyak dibudidayakan karena merupakan komoditas unggulan. Meningkatnya produksi ikan lele berakibat pada penambahan area lahan budidaya dan penggunaan air. Teknologi yang cocok untuk diterapkan adalah sistem akuaponik. Selain menghemat penggunaan lahan dan air, akuaponik juga menigkatkan efisiensi usaha melalui pemanfaatan hara dari sisa pakan dan metabolisme ikan. Kualitas air merupakan faktor penting untuk menunjang keberhasilan budidaya. Pemeliharaan ikan lele dengan penambahan probiotik dalam sistem akuaponik dapat menjadi solusi untuk mempertahankan kualias air, karena mengandung bakteri yang dapat meningkatkan perubahan nitrit menjadi nitrat sehingga dapat dimanfaatkan tanaman untuk pertumbuhannya dan tidak meracuni ikan. Tujuan dari penelitian ini adalah untuk mengetahui pengaruh pemberian probiotik berbeda dalam sistem akuaponik terhadap laju pertumbuhan dan survival rate ikan lele. Penelitian ini menggunakan metode eksperimental dengan Rancangan Acak Lengkap (RAL), terdiri atas empat perlakuan dan lima kali ulangan yaitu P0 (kontrol), P1 (probiotik A), P2 (probiotik B) dan P3 (probiotik C). Analisis data diolah dengan menggunakan Analysis of Variance. Bila terdapat pengaruh perbedaan maka dilanjutkan Uji Jarak Berganda Duncan. Hasil penelitian menunjukkan bahwa pemberian probiotik dalam sistem akuaponik berbeda nyata $(\mathrm{p}<0,05)$. Dari hasil penelitian disimpulkan bahwa pemberian probiotik dalam sistem akuaponik berpengaruh terhadap laju pertumbuhan dan survival rate ikan lele. Laju pertumbuhan spesifik tertinggi $(0,025 \%$ /hari) dan survival rate tertinggi $(77,8 \%)$ terdapat pada perlakuan $\mathrm{P} 2$. Laju pertumbuhan spesifik terendah $(0,019 \%$ /hari) dan survival rate terendah $(64,4 \%)$ terdapat pada perlakuan $\mathrm{P} 0$ (kontrol).
\end{abstract}

Kata Kunci : Akuaponik, Ikan Lele, Probiotik, Laju Pertumbuhan, Survival Rate, Clarias sp.

\begin{abstract}
Catfish (Clarias sp.) is a freshwater fish that is widely cultivated because it is a leading commodity. Increased production of catfish resulted in extra area of cultivated land and water use. The technology suitable to be applied is aquaponic system. In addition to saving land and water use, Aquaponic is also improving business efficiency through the utilization of nutrients from food remains and fish metabolism. Water quality is an important factor for the success of cultivation. Maintenance catfish with the addition of probiotics in aquaponic system can be a solution for maintaining water quality, because it contains bacteria that can increase nitrite to nitrate changes that can be utilized for growth of plants and do not poison the fish. The purpose of this study was to determine the effect of different probiotics in the aquaponic system towards growth rate and survival rate of catfish. The method that used in this research is experimental with completely randomized design (four treat and five repeated) are PO (control), P1 (probiotic A), P2 (probiotic B) and P3 (probiotic C). Analysis of data processed using Analysis of Variance. If there are significant differences then continued Duncan's Multiple Range Test. The results showed that the giving of probiotics in the aquaponic system is significantly different ( $p<0.05)$. The final conclusion is that the addition of probiotics in aquaponic system affect the growth rate and survival rate of catfish. The highest specific growth rate $(0.025 \% /$ day) and the highest survival rate $(77.8 \%)$ contained in the P2 treatment. The lowest specific growth rate $(0.019 \% /$ day) and the lowest survival rate $(64.4 \%)$ contained in P0 treatment (control).
\end{abstract}

Keywords : Aquaponic, Catfish, Probiotic, Growth Rate, Survival Rate, Clarias sp. 


\section{PENDAHULUAN}

Ikan lele (Clarias sp.) merupakan ikan air tawar yang banyak dibudidayakan hampir di seluruh Indonesia. Hal ini disebabkan karena ikan lele merupakan komoditas unggulan, serta mempunyai prospek pasar yang baik (Yunus dkk., 2014). Keunggulan dari ikan lele antara lain adalah mempunyai kandungan gizi yang cukup tinggi, bernilai ekonomis, memiliki pertumbuhan yang cepat serta cara pemeliharaannya yang mudah (Prayogo dkk., 2012).

Meningkatnya produksi ikan lele berakibat pada penambahan area lahan budidaya dan penggunaan air. Teknologi yang sudah banyak diterapkan oleh pembudidaya untuk mengatasi masalah keterbatasan lahan adalah melakukan budidaya dengan sistem akuaponik (Diver, 2006). Selain menghemat penggunaan lahan dan air, akuaponik juga meningkatkan efisiensi usaha melalui pemanfaatan hara dari sisa pakan dan metabolisme ikan. Akuaponik merupakan sistem resirkulasi yang memanfaatkan kembali air yang telah digunakan dalam budidaya ikan dengan filter biologi berupa tanaman.

Probiotik mengandung sebagian besar mikroorganisme Lactobacillus, Bacillus, Nitrosomonas dan Nitrobacter yang dapat meningkatkan dekomposisi limbah serta dapat meningkatkan kualitas air (Tambunan dkk., 2010). Pemberian probiotik dalam lingkungan perairan diharapkan dapat meningkatkan respon imun terhadap penyakit, memperbaiki sistem pencernaan ikan, memperbaiki kualitas air karena dapat merubah senyawa beracun menjadi tidak beracun, seperti senyawa ammonia dan nitrit melalui proses nitrifikasi (Ghouse, 2015), meningkatkan kelangsungan hidup serta dapat meningkatkan laju pertumbuhan ikan sehingga dapat menunjang peningkatan produksi (Suryaningrum, 2012). Pemeliharaan ikan lele dengan penambahan probiotik dapat menjadi solusi untuk mempertahankan kualitas air, karena mengandung bakteri yang dapat meningkatkan perubahan nitrit menjadi nitrat sehingga dapat dimanfaatkan kangkung untuk pertumbuhannya dan tidak meracuni ikan yang dipelihara. Secara komersil probiotik saat ini sudah banyak diproduksi terutama yang digunakan untuk budidaya ikan air tawar dengan kandungan bakteri yang berbeda-beda, maka perlu dikaji terkait dengan efektivitas penggunaan probiotik komersil tersebut. Atas dasar ini, perlu dilakukan penelitian mengenai pengaruh pemberian probiotik yang berbeda terhadap laju pertumbuhan dan survival rate pada media budidaya ikan lele dengan menggunakan sistem akuaponik. 
MATERI DAN METODE

Tempat dan Waktu Penelitian

Penelitian ini telah dilaksanakan pada tanggal 28 Mei sampai 27 Juni 2016 di Laboratorium Pendidikan Fakultas Perikanan dan Kelautan, Universitas Airlangga, Surabaya.

\section{Alat dan Bahan}

Peralatan yang digunakan pada penelitian ini meliputi bak plastik sebanyak 20 buah dengan ukuran 54 × $32 \times 29 \mathrm{~cm}$, pompa air, pipa pvc 2,5 inci, selang, net pot, timbangan digital, jaring, penggaris, gelas ukur, $\mathrm{pH}$ meter, termometer, DO meter dan spektrofotometer. Bahan yang digunakan dalam penelitian ini adalah benih ikan lele dengan ukuran 5 - $7 \mathrm{~cm}$, tanaman kangkung dengan tinggi 5-10 $\mathrm{cm}$ yang telah disemai terlebih dahulu pada rockwool selama 1-2 minggu, pakan komersil berupa pellet, probiotik komersil A (Lactobacillus casei dan Saccharomyces cerevisiae), probiotik komersil B (Lactobacillus, Nitrosomonas, Bacillus), probiotik komersil C (Nitrosomonas, Nitrobacter, Bacillus) dan bahan uji ammonia (Fenol, Natrium klorida, Natrium nitroprusid, Trinatrium sitrat, $\mathrm{NaOH}$, Natrium hipoklorit, akuades).

\section{Prosedur Penelitian}

Tahapan pertama yang dilakukan pada penelitian ini adalah persiapan alat dan bahan Persiapan dilakukan dengan membersihkan peralatan yang akan digunakan. Peralatan yang digunakan berupa bak plastik yang disterilisasi menggunakan klorin dengan dosis 1,5 ppm yang disebar merata ke dalam air, selanjutnya dikeringkan selama satu hari. Bak plastik yang sudah kering diisi dengan air tawar sebanyak 50 liter. Ikan lele ditebar ke dalam bak plastik dengan kepadatan 2000 ekor/m3, sehingga dalam satu bak dapat ditebar 100 ekor/50 liter air. Sebelum ditebar benih ikan lele diaklimatisasi terlebuh dahulu agar suhu air media selama pengangkutan benih dengan air media pada wadah pemeliharaan sama. Pembuatan sistem akuaponik dengan merangkai pipa pvc berukuran 2,5 inci dan pompa air sehingga terbentuk sistem resirkulasi, kemudian persiapan tanaman yaitu dengan menyemai bibit kangkung pada media rockwool. Jumlah tanaman kangkung yang digunakan adalah 30 batang/ bak. Selama pemeliharaan, ikan lele diberi pakan sebanyak 3 kali sehari yaitu pada pukul 08.00, 12.00 dan 16.00. Pakan ikan lele yang digunakan adalah pakan komersial berupa pellet. Pakan yang diberikan sejumlah $5 \%$ dari total berat ikan yang dipelihara.

Pemeliharaan ikan lele dilakukan dengan penambahan probiotik dalam media budidaya setelah satu minggu pemeliharaan. Dosis probiotik yang digunakan sebanyak $0,25 \mathrm{ml} / \mathrm{L}$ atau 12,5 
ml/ bak. Pemberian probiotik tersebut dilakukan setiap satu minggu sekali. Pengukuran kualitas air yaitu suhu, $\mathrm{pH}$ dan kandungan oksigen terlarut (Dissolved Oxygen) dilakuan setiap hari. Sedangkan untuk uji ammonia diukur setiap tiga hari sekali dengan menggunakan metode spektrofotometer berdasarkan APHA (2005). Perhitungan laju pertumbuhan ikan dilakukan dengan sampling sebanyak $10 \%$ dari total populasi ikan dalam setiap bak, kemudian ditimbang berat total ikan setiap satu minggu sekali dan dihitung berdasarkan rumus. Perhitungan kelangsungan hidup ikan (survival ratel SR) dilakukan pada awal dan akhir dari masa pemeliharaan.

\section{Analisis Data}

Penelitian ini menggunakan metode eksperimental dengan Rancangan Acak Lengkap (RAL). Penelitian ini menggunakan 4 macam perlakuan dengan 5 kali ulangan dengan satu faktor pembeda yaitu pemberian probiotik. Parameter yang diamati adalah laju pertumbuhan dan survival rate ikan lele. Data penelitian dianalisis menggunakan Analysis of Varian (ANOVA) dan dilanjutkan dengan uji lanjutan dengan menggunakan Uji Jarak Berganda Duncan (Duncan's Multiple Range Test) untuk mengetahui perbedaan antara perlakuan yang satu dengan perlakuan yang lainnya (Kusriningrum, 2012). Perhitungan statistik menggunakan aplikasi SPSS versi 16.

\section{HASIL DAN PEMBAHASAN}

\section{Laju Pertumbuhan Spesifik}

Laju pertumbuhan spesifik atau Spesific Growth Rate (SGR) ikan lele berkisar antara 1,850 - 2,386 \%/ hari serta menunjukkan adanya pengaruh yang nyata $(\mathrm{p}<0,05)$ terhadap laju pertumbuhan spesifik ikan lele. Data rata-rata laju pertumbuhan spesifik ikan lele dapat dilihat pada Tabel 1.

Tabel 1. Rata-rata Laju Pertumbuhan Spesifik Ikan Lele (Clarias sp.)

\begin{tabular}{cc}
\hline Perlakuan & $\begin{array}{c}\text { Laju Pertumbuhan Spesifik } \\
(\% / h a r i) \pm \text { SD }\end{array}$ \\
\hline P0 & $1,850^{\mathrm{b}} \pm 0,175$ \\
P1 & $2,107^{\mathrm{ab}} \pm 0,117$ \\
P2 & $2,386^{\mathrm{a}} \pm 0,358$ \\
P3 & $2,163^{\mathrm{ab}} \pm 0,162$ \\
\hline Keterangan : P0 (Kontrol), P1 (Probiotik A 0,25 \\
m1/L), P2 (Probiotik B 0,25 ml/L), P3 (Probiotik C \\
0,25 ml/L). Superskrip yang berbeda pada kolom \\
yang sama menunjukkan terdapat perbedaan yang \\
nyata (p<0,05)
\end{tabular}

Berdasarkan hasil Uji Jarak Berganda Duncan (Duncan's Multiple Range Test) diketahui bahwa laju pertumbuhan spesifik tertinggi terdapat pada perlakuan $\mathrm{P} 2$ yaitu sebesar 2,386 \%/ hari, sedangkan laju pertumbuhan spesifik terendah pada perlakuan P0 (kontrol) yaitu sebesar 1,850 \%/hari. Hal ini menunjukkan bahwa pemberian probiotik pada media pemeliharaan dapat meningkatkan laju pertumbuhan ikan lele dibandingkan tanpa 
pemberian probiotik ke dalam media pemeliharaan. Sesuai dengan pernyataan Lisna dan Insulistyowati (2015) bahwa pertumbuhan ikan meningkat karena pengaruh penambahan probiotik dalam media pemeliharaan sehingga bakteri dalam probiotik selain bekerja untuk memperbaiki kualitas air juga bekerja dalam saluran pencernaan ikan. Pada perlakuan P2 dengan penambahan probiotik B didapatkan hasil pertumbuhan tertinggi dibandingkan dengan perlakuan kontrol yang tanpa penambahan probiotik. Hal ini membuktikan bahwa perlakuan P2 dengan penambahan probiotik $B$ (Lactobacillus, Nitrosomonas dan Bacillus) dalam media pemeliharaan ikan dapat memperbaiki kualitas air sehingga dapat menunjang pertumbuhan ikan. Menurut Ernawati dkk. (2014), Bacillus memiliki enzim ekstraseluler yang dapat membantu pencernaan dan mampu memperbaiki kualitas air melalui penguraian dan perombakan bahan organik dalam air. Menurut Gatesoupe (1999) dalam Zhou and Wang (2014), penambahan bakteri Lactobacillus melalui air dapat berpengaruh juga pada saluran pencernaan ikan. Bakteri Lactobacillus berfungsi meningkatkan daya cerna ikan terhadap pakan sehingga dapat memacu pertumbuhan ikan (Sugih, 2005).

Rendahnya nilai laju pertumbuhan spesifik pada perlakuan P0 (kontrol) dibandingkan dengan perlakuan lainnya diduga karena penurunan kualitas air yang ditunjukkan oleh tingginya kadar ammonia yaitu $0,085-0,460 \mathrm{mg} / \mathrm{L}$. Hal tersebut sesuai dengan pernyataan Lisna dan Insulistyowati (2015) bahwa tingginya kadar ammonia dapat mempengaruhi pertumbuhan ikan, menyebabkan ikan stress, menurunnya nafsu makan, timbulnya penyakit dan menyebabkan kematian. Selain itu pada perlakuan kontrol tidak ditambahkan probiotik pada media pemeliharaan sehingga populasi bakteri yang dapat mengoksidasi bahan organik sedikit (Lisna dan Insulistyowati, 2015).

\section{Survival Rate (SR)}

Hasil penelitian menunjukkan bahwa SR atau tingkat kelulushidupan ikan lele berkisar antara 64,4 - 70,8 \%. Berdasarkan hasil perhitungan Analisis of Varian (ANOVA) menunjukkan adanya perbedaan yang nyata $(\mathrm{p}<0,05)$ terhadap survival rate ikan lele. Data rata-rata survival rate ikan lele dapat dilihat pada Tabel 2.

Tabel 2. Rata-rata Survival Rate Ikan Lele (Clarias sp.)

\begin{tabular}{cc}
\hline Perlakuan & Survival Rate $(\%) \pm$ SD \\
\hline P0 & $64,4^{\mathrm{a}} \pm 1,81$ \\
P1 & $66,4^{\mathrm{a}} \pm 1,94$ \\
P2 & $77,8^{\mathrm{c}} \pm 2,28$ \\
P3 & $70,8^{\mathrm{b}} \pm 4,08$ \\
\hline
\end{tabular}

Keterangan : P0 (Kontrol), P1 (Probiotik A 0,25 $\mathrm{ml} / \mathrm{L}$ ), P2 (Probiotik B 0,25 ml/L), P3 (Probiotik C $0,25 \mathrm{ml} / \mathrm{L}$ ). Superskrip yang berbeda pada kolom yang sama menunjukkan terdapat perbedaan yang nyata $(\mathrm{p}<0,05)$ 
SR tertinggi terdapat pada perlakuan P2 yaitu sebesar 77,8 \%, sedangkan SR terendah pada perlakuan P0 (kontrol) yaitu sebesar 64,4\% yang berbeda nyata dengan perlakuan P2 dan P3. Pada perlakuan P1, P2 dan P3 mortalitas ikan juga terjadi, namun tidak sebanyak mortalitas ikan uji pada perlakuan P0 (kontrol). SR terendah pada perlakuan P0 disebabkan karena banyaknya ikan yang mati, hal tersebut diduga karena ikan mengalami stress akibat kadar ammonia yang cukup tinggi. Konsentrasi ammonia pada perlakuan P0 (kontrol) lebih tinggi dibandingkan dengan perlakuan lainnya yaitu berkisar antara $0,085-0,460 \mathrm{mg} / \mathrm{L}$. Konsentrasi ammonia yang tinggi juga berpengaruh terhadap tanaman pada sistem akuaponik, karena akar tanaman tidak dapat memanfaatkan nitrat secara optimal untuk pertumbuhannya, karena nitrat merupakan hasil penguraian dari ammonia (Tambunan dkk., 2010).

Tingginya SR pada perlakuan P2 (probiotik B) dibandingkan dengan perlakuan yang lain disebabkan karena kualitas air yang baik dan sesuai untuk kehidupan ikan. Hal ini sesuai dengan pernyataan (Lisna dan Insulistyowati, 2015), bahwa kualitas air sangat berpengaruh terhadap SR dan pertumbuhan ikan. Selain itu tingginya nilai SR pada perlakuan P2 juga disebabkan karena pemberian probiotik secara berkala yaitu setiap satu minggu sekali, sehingga membantu memberikan kondisi ekosistem air yang ideal baik dalam hal efisiensi penyerapan pakan dan proses nitrifikasi (Hartini dkk., 2013). Bakteri dalam probiotik B seperti Bacillus dan Nitrosomonas bekerja secara efektif untuk menguraikan bahan organik sehingga kualitas air tetap stabil. Hal tersebut sesuai dengan pernyataan Pitrianingsih dkk. (2014), bahwa bakteri Bacillus sangat baik digunakan untuk memperbaiki kualitas air pada media budidaya. Hal tersebut terbukti bahwa pada perlakuan P2 konsentrasi ammonia paling rendah diantara perlakuan lainnya yaitu berkisar antara 0,077 - 0,313 $\mathrm{mg} / \mathrm{L}$.

\section{Kualitas Air}

Data nilai kisaran kualitas air dapat dilihat pada Tabel 3. Berdasarkan hasil pengukuran suhu selama penelitian pada semua perlakuan tidak menunjukkan perbedaan yang signifikan. Suhu berkisar antara $28-30{ }^{\circ} \mathrm{C}$. Kisaran suhu ini masih dalam keadaan layak untuk pemeliharaan ikan lele yaitu $22-32{ }^{\circ} \mathrm{C}$ (BBPBAT, 2005). Lucas (2002), menyatakan bahwa suhu media yang optimum berpengaruh terhadap kinerja enzim pencernaan dan metabolisme yang efektif. Konsumsi pakan yang tinggi disertai dengan proses pencernaan dan metabolisme yang efektif akan 
menghasilkan energi yang optimal untuk pertumbuhan (Zidni dkk., 2013).

Hasil pengukuran $\mathrm{pH}$ air selama penelitian didapatkan hasil berkisar antara 7,0 - 8,1. Nilai kisaran $\mathrm{pH}$ selama penelitian masih memenuhi kisaran yang layak untuk pemeliharaan benih ikan lele yaitu berkisar antara 6 - 9 (BBPBAT, 2005). Terjadinya fluktuasi $\mathrm{pH}$ selama penelitian untuk setiap perlakuan diduga disebabkan oleh adanya pelepasan dan pengambilan karbondioksida $\left(\mathrm{CO}_{2}\right)$ oleh organisme yang ada di dalam media pemeliharaan (Lisna dan Insulistyowati, 2015). Kisaran kandungan oksigen terlarut/ Dissolved Oxygen (DO) dalam air pemeliharaan ikan lele adalah 4,16 - 5,81 mg/ L. Nilai kisaran oksigen terlarut dari hasil pengamatan ini masih memenuhi kisaran yang layak untuk pemeliharaan ikan lele yaitu $>3 \mathrm{mg} / \mathrm{L}$ (BBPBAT, 2005). Fluktuasi oksigen terlarut dalam bak pemeliharaan pada semua perlakuan hampir sama, hal ini dikarenakan adanya tanaman kangkung air pada sistem akuaponik. Tanaman kangkung air melakukan aktifitas fotosintesis pada siang hari dan fitoplankton yang menghasilkan $\mathrm{O}_{2}$ sehingga oksigen terlarut pada setiap kolam relatif sama meskipun terjadi fluktuasi yang cukup signifikan.

Hasil pengukuran kadar ammonia selama penelitian pada semua perlakuan berkisar antara 0,062 - 0,460 mg/ L. Kadar ammonia tertinggi terdapat pada perlakuan P0 (kontrol) yaitu 0,085 - 0,460 mg/ L. Hal ini disebabkan karena pada perlakuan P0 (kontrol) tidak ditambahkan probiotik pada media pemeliharaan ikan lele, sehingga terjadi penumpukkan bahan organik di dasar bak yang berasal dari sisa pakan dan hasil metabolisme ikan dan tidak terdekomposisi seluruhnya oleh bakteri pengurai. Namun kadar ammonia pada perlakuan P0 (kontrol) masih dalam kisaran layak dan aman untuk pemeliharaan ikan lele, hal ini sesuai dengan pernyataan BBPBAT (2005) bahwa kadar ammonia pada pemeliharaan ikan lele $<0,8 \mathrm{mg} / \mathrm{L}$.

Tabel 3. Kisaran Kualitas Air Pemeliharaan Ikan Lele

\begin{tabular}{ccccc}
\hline Perlakuan & \multicolumn{4}{c}{ Parameter } \\
\cline { 2 - 5 } & Suhu $\left({ }^{\circ} \mathrm{C}\right)$ & $\mathrm{pH}$ & $\mathrm{DO}(\mathrm{mg} / \mathrm{L})$ & Ammonia $(\mathrm{mg} / \mathrm{L})$ \\
\hline P0 & $28-30$ & $7,0-8,0$ & $4,16-5,17$ & $0,085-0,460$ \\
P1 & $28-30$ & $7,2-8,0$ & $4,17-5,31$ & $0,062-0,350$ \\
P2 & $28-30$ & $7,1-8,0$ & $4,20-5,81$ & $0,077-0,313$ \\
P3 & $28-30$ & $7,3-8,1$ & $4,17-5,41$ & $0,091-0,348$ \\
\hline
\end{tabular}

\section{KESIMPULAN DAN SARAN}

Kesimpulan yang diperoleh dari penelitian ini adalah pemberian probiotik dalam sistem akuaponik dapat meningkatkan laju pertumbuhan dan survival rate ikan lele (Clarias $\mathrm{sp}$.) sebagai perlakuan tertinggi yaitu nilai laju pertumbuhan spesifik sebesar 2,386 \%/ hari 
dan nilai SR sebesar 77,8\%. Probiotikkomersil terbaik yang dapat meningkatkan laju pertumbuhan dan survival rate ikan lele adalah probiotik komersil B yang berisi bakteri (Lactobacillus, Nitrosomonas dan Bacillus) dengan penggunaan dosis $0,25 \mathrm{ml} / \mathrm{L}$.

Berdasarkan hasil penelitian yang telah dilakukan, pemberian probiotik komersil B (Lactobacillus, Nitrosomonas, Bacillus) dapat menghasilkan laju pertumbuhan dan SR yang tinggi, sehingga probiotik komersil B dapat digunakan pada budidaya ikan lele (Clarias sp.) dalam sistem akuaponik dengan harapan dapat mengurangi tingkat konsumsi air dan dapat digunakan untuk meningkatkan produksi budidaya. Dapat dilakukan penelitian selanjutnya tentang pemberian dosis yang berbeda guna mencari dosis yang tepat.

\section{DAFTAR PUSTAKA}

[APHA] American Public Health Association. 2005. Standard methods for examination of water and waste water, 21st ed. APHA. Washington. DC.

Balai Besar Pengembangan Budidaya Air Tawar (BBPBAT). 2005. Petunjuk Pembenihan Ikan Lele (Clarias sp.). Sukabumi. 6 hal.

Diver, S. 2006. Integration of Hydroponics with Aquaculture. National Suistanable Agriculture Information Service. Australia. 28 p.

Djokosetiyanto, D., A. Sunarma dan Widanarni. 2006. Perubahan Ammonia (NH3), Nitrit (NO2) dan
NItrat (NO3) Pada Media Pemeliharaan Ikan Nila Merah (Oreochromis sp.) di Dalam Sistem Resirkulasi. Jurnal Akuakultur Indonesia, 5 (1): 13-20.

Ernawati, D., Prayogo dan B. S. Rahardja. 2014. Pengaruh Pemberian Bakteri Heterotrof terhadap Kualitas Air pada Budidaya Lele Dumbo (Clarias sp.) Tanpa Pergantian Air. Fakultas Perikanan dan Kelautan. Universitas Airlangga. Surabaya. 10 hal.

Ghouse, M. 2015. Use of Probiotics as Biological Control Agents in Aquaculture For Suistanable Development. Departement of Zoology. Osmania College. India. pp 112-119.

Iqbal, M. 2011. Kelangsungan Hidup Ikan Lele (Clarias gariepinus) pada Budidaya Intensif Sistem Heterotrofik. Skripsi. Fakultas Sains dan Teknologi. Universitas Islam Negeri Syarif Hidayatullah. Jakarta. 85 hal.

Kementerian Kelautan dan Perikanan. 2014.http://www.djpb.kkp.go.id/berit a. Diakses tanggal 15 Februari 2015.

Kusriningrum, R. S. 2012. Buku Ajar Perancangan Percobaan. Cetakan Keempat. Dani Abadi. Surabaya. hal 6-18.

Lisna dan Insulistyowati. 2015. Potensi Mikroba Probiotik_FM dalam Meningkatkan Kualitas Air Kolam dan Laju Pertumbuhan Benih Ikan Lele Dumbo (Clarias gariepinus). Fakultas Peternakan. Universitas Jambi. Mendalo. 8 hal.

Pitrianingsih, C., Suminto dan Sarjito. 2014. Pengaruh Kandidat Probiotik Terhadap Perubahan Kandungan Nutrien C,N,P dan K Melalui Kultur 
Lele Dumbo (Clarias gariepinus). Fakultas Perikanan dan Ilmu Kelautan. Universitas Diponegoro. Semarang. 10 hal.

Prayogo, B. S. Rahardja dan A. Manan. 2012. Eksplorasi Bakteri Indigen pada Pembenihan Ikan Lele (Clarias sp.) Sistem Resirkulasi Tertutup. Fakultas Perikanan dan Kelautan. Universitas Airlangga. Surabaya. 5 hal.

Sugih, F. H. 2005. Pengaruh Penambahan Probiotik dalam Pakan Komersil terhadap Pertumbuhan Benih Ikan Gurami. Skripsi. Fakultas Perikanan dan Ilmu Kelautan. Universitas Padjajaran. Jatinangor. 7 hal.

Suryaningrum, F. M. 2012. Aplikasi Teknologi Bioflok pada Pemeliharaan Benih Ikan Nila (Oreochromis niloticus). Tesis. Program Pasca Sarjana. Universitas Terbuka. Jakarta. 89 hal.

Tambunan, E. P., U. M. Tang dan Mulyadi. 2010. Cultivation of River Catfish (Mystus nemurus) in Aquaponic Resirculation System With The Addition of EM4. Fakultas Perikanan dan Imu Kelautan. Universitas Riau. 6 hal.

Taufik, I., H. Supriadi, I. Muthalib, P. Yulianti dan S. Subandiyah. 2005. Studi Pengaruh Suhu Air terhadap Aktivitas Bakteri Bioremediasi (Nitrosomonas dan Nitrobacter) pada Pemeliharaan Benih Ikan Patin Siam (Pangasius pothalamus). Jurnal Perikanan Indonesia. hal 59-66.

Zhou, X and Y. Wang. 2014. Probiotics in AquacultureBenefitss to the Health, Technological Applications and Safety. College of Biological and Enviromental Engineering. Gongshang University. China. 14 p.
Zidni, I., T. Herawati dan E. Liviawaty. 2013. Pengaruh Padat Tebar Terhadap Pertumbuhan Benih Lele Sangkuriang (Clarias gariepius) dalam Sistem Akuaponik. Fakultas Perikanan dan Ilmu Kelautan. Universitas Padjajaran. Bandung. 10 hal. 